\title{
Global Processes of Flight and Migration: How Case Studies Help to Understand Their Complex and Heterogeneous Character
}

\author{
Eva Bahl, Johannes Becker
}

\section{The Explanatory Power of Case Studies}

Our aim in this volume is to show the explanatory power and the potential of case studies for analyzing flight and migration processes. They enable us to deconstruct discursive and media images of huge numbers of faceless people, all moving northward or westward in similar ways and along similar paths. Case studies reveal the complexity and heterogeneity of flight and migration processes as historical and social phenomena embedded in individual, familial and collective histories, and closely tied up with the history of nation states, regions, towns and we-groups. We will counter a still common assumption in the social sciences, namely that case studies cannot serve as a basis for generalization and theory building and are mainly useful for conducting preliminary studies. In this volume we make use of "the force of example" (Flyvbjerg 2006: 228) to make social processes accessible by means of indepth analyses. We focus on particular cases and their genesis, and we make systematic comparisons of selected cases. This approach enables us to identify and to reconstruct the "deeper causes behind a given problem and its consequences" (ibid.: 229). On the groundwork of the case analyses, it is possible to make theoretical 
generalizations from the construction of various types (see for example Weber 1949[1904]; Lewin 1992[1927]; Schuetz 1953; Oevermann 1981), from thick descriptions of social phenomena and contexts (Geertz 1973), or simply by formulating general conclusions. Thus, case analyses can serve as a means of constructing grounded theories (Glaser/Strauss 2008[1967]). The structure of a case can tell us something about a bigger whole, assuming that there is a dialectical relationship between the part and the whole (Rosenthal 1995: 27 ff.). There can be different case levels: in this volume these include migration groupings, migration routes, and in particular family histories and individual biographies. ${ }^{1}$

In concrete terms, we understand case studies relating to flight and migration as detailed and in-depth empirical analyses of the geographical contexts of origin and arrival of the migrants, the course of their flight or migration, and their personal or family history; these are always considered in their interrelation with the relevant historical and socio-economic context. In other words, case studies involve far more than just individual cases when they are embedded in consistent societal analyses. Case analyses differ from the reproduction of individual histories when the migration processes and the positions of the actors are socially and historically embedded. There is an interrelationship between individuals and the social processes of which they are part (Fischer/Kohli 1987; Rosenthal 2012) which makes it possible, for instance, to analyze how flight and migration phenomena are entangled with far-reaching short- and long-term social transformation processes. At the same time, in such case analyses it is important to pay attention to the perspective of the actors, and to take their interpretations and relevancies seriously. With case analyses, it is thus possible to show that refugee migrations are complex processes which may involve phases of agentic power or phases of suffering and are bound up with decisions and ambitions that go far beyond the bare act of leaving one's home. Yet these apparently individual aspects are embedded in the wider dynamics of migration arising from things like unequal global and local power relations, dynamic border regimes and immigration policies, and - often connected with these - changes of route, as well as historical coincidences that influence the migration process. Also on the level of the actors, differences between the experience of flight and later memories of it can be analyzed, together with changing belongings and definitions of migration, and their interrelationship with discourses in the society of origin and the society of arrival. In this respect, starting with individual cases thus has the advantage that processes and experiences of flight can be described and reconstructed in their social embedment: life before the migration, the frequently complex and long journey, and arrival, whether temporary or permanent (Worm 2019; cf. BenEzer/Zetter 2014).

\footnotetext{
${ }^{1}$ Charles C. Ragin (1992: 4) has argued that panel studies or surveys can also be referred to as case studies. He thus criticized the equating of case studies with qualitative research, and pointed out that an ethnographer and a scholar using quantitative methods who study the same phenomenon can both be said to be making a case study. However, studies aiming at breadth or statistical representativeness are not case studies in the sense that we use the term.
} 
The authors of the articles collected here have in common a paradigmatic positioning in interpretive or reconstructive social research. In general terms, this means that the analyses are focused on the perspectives and the histories of action or courses of activity of the persons concerned. This enables us to gain a more nuanced view of complex migration phenomena in their social and historical contexts, and of the experiences of migrants. Many of the authors are active in the field of socialconstructivist biographical research. A biographical approach has the advantage that histories of migration and flight can be reconstructed in their processuality, and migration courses can be interpreted in terms of their relationship to the whole biography, and their entanglement with relevant collective histories (see Becker forthcoming; Rosenthal 2016; Rosenthal/Bahl/Worm 2017).

In our view, the explanatory power of case studies in the context of migration and refugee research is that they enable us to map a wide range of experiences of flight and migration, and to reconstruct both rare and common cases. The articles in this edited volume illustrate both aspects of the explanatory power of case studies. Within a broad spectrum of refugee migrations, the relevance and structure of rare cases can be made visible. This also applies to flight courses which empirical data show to be more common and which can be described in more detail. Using case studies to focus on concrete experiences along routes commonly used by refugees makes it easier to see the differences in what might otherwise appear to be uniform experiences of migration. Detailed case analyses offer an opportunity to uncover structural features of migration processes. On the basis of this knowledge, it is possible, and very fruitful, to make a contrastive comparison of different cases - and of the different articles within this volume. Thus, refugee routes, experiences and strategies can be described and understood from different perspectives with a view to developing theoretical insights. To illustrate the potential of such a comparison, we discuss below three aspects which can be considered across many of the articles.

A theme that frequently recurs is the question whether a particular mobility phenomenon can be described as flight, migration, or both - in parallel or at different times. The problems associated with making a dichotomous distinction between flight and migration arises more or less explicitly in most of the articles. This is linked to the authors' observation that migration results from a constellation whose character may change (more than once) or remain ambivalent during the process of migration. This is a question that is currently receiving increasing attention in refugee and migration studies. The case studies in this volume can provide some answers. Gabriele Rosenthal and Lukas Hofmann show that the categories of flight and migration fail to do justice to the complexity of migration courses in which phases of agentic power alternate with phases of powerlessness. Johannes Becker and Hendrik Hinrichsen show that the process of flight may be entangled with other migration ideas. Fabio Santos points out that the established distinction between flight and migration can lead to the exclusion of people who are in urgent need of protection mechanisms. And in the article by Lucas Cé Sangalli and Maria do Carmo dos Santos Gonçalves the two interviewees both position themselves as migrants, even though 
they have been granted refugee status. While "refugee" as a legal category tends to homogenize their situations, reconstruction of their biographies shows how dominant discourses in the societies they lived in shaped their self-presentations at the time of the interview.

The definition of oneself as a migrant and/or refugee is just one example of another topic that arises in all the articles: how the perspectives of migrating people change in the course of their migration process, and how experiences may be reinterpreted as a result of new layers of experience. Katharina Inhetveen's analysis shows how the perspectives of Angolans who have spent many years in Zambian refugee camps change after their return home or re-migration. Ludger Pries, Christian Schramm and Melanie Wieschalla discuss the case of Eduardo, a young Mexican who migrated to the US with his family when he was a child, and who was expelled when he was 23 because of his involvement with criminal gangs. They discuss violence as a constant which accompanies his migration and his (forced) re-migration. They show how Eduardo's perspectives changed as a result of his arrest and the violent death of other gang members, and due to new educational opportunities. And they underline that the interpretation of violence is always dependent on the particular context and particular interactions.

A third issue that runs through many of the articles in this volume is the relationship between those who leave and those who stay. Steve Tonah and Emmanuel Codjoe investigate the effects of migration on members of the family who have stayed in Ghana. On the one hand, it brings them a certain degree of respect and prestige, but on the other hand, they constantly worry about their relatives, wondering where they are and what kind of situation they are in. Sevil Çakır-Kılınçoğlu shows how politically active exiles constantly refer to developments in their context of origin. And Katharina Inhetveen discusses the sociological necessity of examining the motives of those who choose to stay. While migration is frequently regarded as an exception to the rule, and thus as being in need of explanation, she argues that deciding to stay, especially in the context of war and collective violence, should be seen as a social phenomenon worthy of investigation.

\section{Global Processes of Flight and Migration}

The articles in this volume throw light on flight processes in their global dimension. By this we mean not only transcontinental migration processes, but also the fact that migration can occur in any part of the world. The articles focus in particular on migration within the Global South. ${ }^{2}$ This is by far the most frequent kind of migra-

\footnotetext{
2 We use the term "Global South" although we are aware that such global categorizations should never be used uncritically. It is important to reflect on how far they reproduce the idea that countries can be divided into "developed" and "underdeveloped", or "industrial", "developing" and "emerging". Stephanie J. Nawyn (2016: 168) claims that the term "Global South" is not precise enough to describe the complex economic, political and social interrelationships that cut across national borders. She
} 
tion (Baeninger et al. 2018; Nawyn 2016), and yet it has attracted insufficient attention among sociologists in the Global North. For this reason, it is brought to the fore in the first two sections of this volume. These articles show that Europe, or the Global North in general, does not play the central role as a migration destination that is suggested by European or Northern political and media discourses. We counter these discourses by presenting empirically based analyses that reveal the global dimension of migration movements. This is a significant contribution to widening perspectives on these issues, and helps to show that non-European countries are not exclusively "sender" countries but also important host societies. Several of the articles in this volume are interesting in this respect and throw light on the living conditions of refugees in Zambia (Inhetveen), Uganda (Rosenthal/Hofmann), Libya (Tonah/Codjoe), Jordan (Becker/Hinrichsen), and Brazil (Cé Sangalli/dos Santos Gonçalves).

Albeit from different perspectives, all the articles in this volume consider the experiences of refugees before their decision to leave, during the process of migration, and in their (often temporary) "host countries". Also in the articles in the third section, which thematize arrival contexts in Europe, the experiences of refugees in their spaces of origin play an important role; the migration and living conditions of refugees are embedded in each case in the respective specific historical, social and geographical contexts. This helps to counter the homogenization of different groupings of refugees. The articles are briefly summarized below within the framework of the three thematic clusters, and in a comparative fashion.

The first section is devoted to "Complex Flight and Migration Processes Worldwide: Transit, Hubs, Networks". This section mainly contains articles on transcontinental South-South migrations, in which Europe or some other part of the Global North is a destination only in certain cases, and only temporarily (whether by choice or not). This challenges Eurocentric conceptions that there are typical patterns of routes that refugees all over the world follow, and clearly reveals the dynamic and processual nature of refugee migration. The different case studies show that flight and migration movements are global phenomena. Moreover, they reveal certain important hubs or crossroads, because in the cases discussed in this section there is some significant overlapping in respect of the places where refugees have stayed and the routes they have followed.

Fabio Santos discusses the continuing migration of a young man from Cameroun, who traveled via Niger and Libya to the Spanish enclaves in Northern Africa, Ceuta and Melilla, from there to Spain, and finally to Brazil and French Guiana. The author interprets Célestin's biography as an attempt to escape from the "lottery of birth" and to improve his social situation in a context of global inequality.

argues that a close examination of established distinctions and categories is needed, and adds that researchers in the field of migration studies are in a very good position to do this. 
While Libya in the early 2000s was experienced by Célestin as a dangerous place where migrants were exploited, Steve Tonah and Emmanuel Codjoe show that during a different historical period Libya had positive connotations as a destination country for migrants within West Africa. When, in the 2000s, first the Italian government and then the European Union began to cooperate with Gaddafi's government, the situation for migrants in Libya became increasingly precarious, with the result that more and more of them decided to continue their migration by crossing the Mediterranean.

Arne Worm writes about refugees from the civil war in Syria who, like Célestin in Santos's article, crossed the external border of the European Union between Morocco and the Spanish enclaves of Ceuta and Melilla. It is rare for Syrian refugees to follow a route that leads across this border, but it offers a chance to reach Europe without embarking on a dangerous crossing of the Mediterranean. ${ }^{3}$ Worm presents a typology which categorizes the different ways in which transnational experiences are interrelated with the choice of migration route.

Lucas Cé Sangalli and Maria do Carmo dos Santos Gonçalves discuss the case of Karim Ishatu from Ghana, who, like Célestin, migrated from West Africa to South America. Besides giving this example of a form of migration about which very little is known in European contexts, they examine the interrelationships between political contexts, social and legal rules, and familial circumstances and interests which constitute the initial constellation and starting point of migration processes. These interrelationships are also shown in the second case they introduce, that of a Haitian who, after living for several years in the Dominican Republic, migrated to Brazil via Ecuador.

Gabriele Rosenthal and Lukas Hofmann focus on the situation of Eritrean refugees in Uganda, thus throwing light on a highly complex migration phenomenon. In most of the cases they discuss, the individuals concerned had lived for many years in Israel before being deported from there to Uganda. In some cases, they had first been sent to Rwanda, where they were not given residence permits and therefore decided to move to Uganda. They all harbor a wish to move on. For the time being they are stranded in Kampala, the capital of Uganda, but they regard it only as a stopping place and hope that they will get an opportunity to travel to a country in the Global North.

In the articles in this section, a special role is played by transit countries or routes (cf. Düvell/Molodikova/Collyer 2014; Trzeciak/Tuider/Wienold 2018), which are spaces in which refugees from different regions make contact and share common experiences. This applies especially to the so-called desert route and Libya (Santos; Tonah/Codjoe), and Morocco, Ceuta and Melilla (Santos; Worm). A comparison of these chapters shows that they describe similar situations and challenges (such as border crossings), but that the way refugees experience these situations depends very

\footnotetext{
3 The situation for Syrians at the borders of Ceuta and Melilla is very different from the challenges faced by Black migrants. On this racialized border regime, see Rosenthal/Bahl/Worm 2017.
} 
much on the historical time, their context of origin, their social, cultural and economic capital, and their available networks. This is very clear if we consider how Santos discusses the efforts of West African migrants to cross the dangerous fences at Melilla, which is a tremendous physical challenge, while the Syrians presented by Arne Worm could rely on their language skills and the racializing ascriptions of the border guards to get them across the very same border, a much less dangerous and difficult exercise than climbing over the fences. Another good example is the way Libya changed from being an attractive destination for Ghanaians to being a highly dangerous country for West African migrants (Tonah/Codjoe; Santos). The articles in this section also show how a place where migrants have lived, in some cases for many years, can become a transit space when a new political situation forces them to move on. Ghanaian migrants decided to leave Libya and cross the Mediterranean (Tonah/Codjoe), Syrian refugees who had planned to stay in Algeria, and who in some cases had lived there for several years, finally decided to leave and try to reach Europe (Worm), and most of the Eritreans stranded in Kampala had regarded Israel as their destination and had found work there and founded families before being forced to leave by the government authorities (Rosenthal/Hofmann).

After these chapters on transregional or global migration, the second part of this volume is devoted to studies of refugees who have stayed within the same region or state, especially in the context of violence and war, and whose migration may be temporary, i.e. followed by re-migration. It is a fact that most people who leave their homes seek refuge (at least initially) in neighboring regions or countries (see Oltmer 2017: 728). Some are accommodated in spatially isolated refugee camps (see Inhetveen 2013; Krause 2017), while others live in towns and communities and are integrated in daily life there. The legal status and living conditions of refugees differ from country to country and from region to region.

Using data from her ethnographic research in refugee camps in Zambia and with returnees or re-migrants in Angola, Katharina Inhetveen looks at how the perspectives of Angolan refugees on their life during their time in Zambia change after their return or re-migration to Angola.

Ludger Pries, Christian Schramm and Melanie Wieschalla describe how daily life in Mexico is dominated by violence, which is one reason why people decide to migrate. They show that migration does not necessarily provide protection, but is frequently "accompanied" by violence, which can be seen as a continuity in transnational biographies between Mexico and the US. And when young people return or are forced to re-migrate to Mexico, the violent structures frequently continue there.

Johannes Becker and Hendrik Hinrichsen discuss the case of an Iraqi family and their long migration, first within Iraq, and then to the neighboring country of Jordan, and use it to question the "regionalism assumption" in Middle East migration research. This says that migration to a context that is culturally and geographically similar is less destabilizing for established certainties and routines than migration over long distances or between contexts that are culturally and linguistically very different. 
As seen in the above short presentation of the first two sections, a transnational perspective is common to many of the articles in this volume. It is needed in order to do justice to the complexity of migration processes and the diverging living conditions of refugees, which are always embedded in particular political, legal and socio-cultural contexts. The same conclusions that have been reached in studies on transnationalism apply here to refugee migration: it is not just a matter of leaving one nation-state container and moving to another, of tearing up roots and putting down new roots. Rather, migration is often (intentionally or unintentionally) circular, in other words people travel back and forth, whether because of their precarious residency status, or because they are deported, or because they wish to support family members who have stayed behind. Family and other social networks play a vital role in making the decision to leave and in the choice of destination and route, as well as in the emergence of transnational social spaces which also involve those who stay behind and who may never cross a border themselves. ${ }^{4}$

In the articles discussed so far, this can be seen for example in cases of "stranded refugees" who had originally chosen a different destination (Rosenthal/Hofmann; Becker/Hinrichsen), deportees (Pries/Schramm/Wieschalla; Rosenthal/Hofmann), migrants who decide to move on after some time (Santos; Worm), or to re-migrate (Tonah/Codjoe; Inhetveen), ${ }^{5}$ or who chose a particular (temporary) destination because of their family's history (Worm); here longstanding transnational family networks play a significant role (see Becker/Hinrichsen/Worm in press). Many of the analyses in the first two sections of this book thus reveal once more the sociological potential of combining transnational perspectives with biographical research, as has already been discussed in the literature, ${ }^{6}$ in this volume with a special focus on refugee migration in the Global South.

This transnational perspective is also important in the third section which is mainly devoted to different European arrival contexts. The authors in this section thematize, for example, the transnational space of Kurdish political activists between Germany and different parts of Kurdistan (Çakır-Kılınçoğlu), the multiple migrations of Roma people between Serbia/Kosovo and Germany, especially during the past thirty years (Blume-Peiffer), and complex negotiations of belonging between different national contexts (Mijić; Taboada Gómez).

Also common to all the articles in this section is that the authors avoid focusing one-dimensionally on concepts such as "integration in the host society" or the

\footnotetext{
${ }^{4}$ For a basic discussion of this topic, see for instance Berriane/de Haas/Natter 2015; Glick Schiller/ Blanc-Szanton/Basch 1992; Minteu Kadje 2017; Portes 1997; Pries 2019; Setrana/Tonah 2014, 2016; Tonah 2007.

5 On re-migration in general, see Nieswand 2011.

${ }^{6}$ On migrants from other EU countries or former recruiting countries, and labour migration for the purpose of care or domestic work, see for example Apitzsch/Siouti 2014; Brandhorst 2017; Karakayal 2010; Lutz 2004; Siouti 2017.
} 
"causes of migration", which do not do justice to the complexity and heterogeneity of the migration and living conditions of refugees. An approach that goes "beyond the integration paradigm" (Hess 2014) has often been called for in recent years (see Castro Varela 2013; Hess/Binder/Moser 2009; Treibel 2015).

Ana Mijic discusses the ambivalent belongings of a woman from Vienna whose family left Bosnia when she was a child: she is torn between feelings of guilt because she did not live through the war, a desire to "belong" and to be recognized as a Bosnian, idealization or denigration of her parents' place of origin, and fragmented memories. Even if their strategies for coming to terms with their past are very different, the situation of people who were forced to leave their country as children is a topic that runs through several chapters.

Victoria Taboada Gómez discusses this in the light of the biography of a woman who came as a refugee to East Germany with her mother when she was a child, and who finally found a "home" for herself in the context of anti-racist activism, after negotiating her own painful experiences of racism and her orientation toward South America and West Germany. Taboada Gómez uses this case to analyze the way the categories of "migrant" and "refugee" are intertwined along the woman's life course.

The topic of activism forms a link between this and the article by Sevil CakerrKılınçoğlu. She compares the cases of an Iranian Kurd and a Turkish Kurd who see themselves as exiles and who still focus their political work on their region of origin and the situation of Kurdish people. Despite many common features between them, Çakır-Kılınçoğlu shows how their present positioning and activist praxis is affected by their different contexts of origin and their very different courses of migration.

On the basis of her multigenerational study of Roma families in Germany and Serbia, Doreen Blume-Peiffer reveals the importance of historical knowledge (or ignorance) concerning the role of members of one's own family in the resistance during the Second World War, or as victims of Nazi persecution. She shows how a precarious residence status in Germany makes it more difficult to process traumatizing experiences, and how transnational networks emerge as a result of (forced) re-migration.

The importance of a person's residence status for the processing of trauma experienced before and during migration is also shown clearly by Christian Jorgow, who reconstructs the biographies and migration histories of two Yazidi women from Iraq. In the first case, the woman distanced herself from Yazidism and embarked on an emancipation process that helped her to cope with the consequences of what she had suffered. By contrast, the other woman's affirmation of her Yazidi belonging promised stabilization.

Thus, the articles in this section examine complex negotiations in respect of engagement and belonging (Çakır-Kılınçoğlu; Mijić; Taboada Gómez), or analyze debilitating struggles over legal and social recognition in arrival contexts that are often perceived as being unsupportive or even hostile (Jorgow; Blume-Peiffer). The way the conditions and opportunities for participation are experienced - in their constant interrelationship with changing discourses and legal regulations - is a theme that 
runs through all the articles. They mirror the diversity of positions in which migrants find themselves in European arrival contexts. It is clear that "arrival" is a process that can last for decades and tends to remain unfinished. It is a process that oscillates between struggles in respect of the place of origin with its associated loyalties, and rejection in the present, and it is a process that some of the persons discussed here may still have before them.

Acknowledgments. We are very pleased that both young and established academics agreed to be part of this edited volume. We would like to express our thanks to all of them for their contributions and for their cooperation. We are also grateful to the editors of the "Göttingen Series in Sociological Biographical Research" for their valuable support in producing this book. Our thanks also go to the anonymous reviewers, to Sabrina Krohm and Friederike von Ass for their help with formatting issues, and to Ruth Schubert for translation and English language editing services.

\section{References}

Apitzsch, U./Siouti, I. (2015): Transnational Biographies. In: Zeitschrift für Qualitative Forschung, 15(1/2), 12-23.

Baeninger, R./Bógus, L. M./Moreira, J. B./Vedovato, L. R./Fernandes, D. M./Souza, M. R. d./Baltar, C. S./Peres, R. G./Waldman, T. C./Magalhães, L. F. A. (eds.) (2018): Migrações Sul-Sul. Online: http://nempsic.paginas.ufsc.br/files/2015/02/LIVROMIGRA\%C3\%87\%C3\%95ES-SUL-SUL.pdf <21.03.2018>.

Becker, J. (in press): Refugees, Migration and the Tightening Borders in the Middle East. Perspective from Biographical Research on the Re-Figuration of Spaces and Cross-Cultural Comparison. In: Baur, N./Mennell, S./Million, A. (eds.): The Re-Figuration of Spaces and Cross-Cultural Comparison. Forum: Qualitative Social Research.

Becker, J./Hinrichsen, H./Worm, A. (in press): Fluchtmigration von Syrien nach Jordanien im familiengeschichtlichen und regionalhistorischen Kontext. Zum Nutzen einer biographietheoretischen und figurationssoziologischen Forschungsperspektive. In: Köttig, M./Witte, N. (eds.): Biographien in Gesellschaft. Weinheim: Beltz Juventa.

BenEzer, G./Zetter, R. (2014): Searching for Directions. Conceptual and Methodological Challenges in Researching Refugee Journeys. In: Journal of Refugee Studies, 28(3), 297-318.

Berriane, M./De Haas, H./Natter, K. (2015): Introduction. Revisiting Moroccan Migrations. In: The Journal of North African Studies, 20(4), 503-521. 
Brandhorst, R. M. (2017): “A lo lejos”. Aging in Place and Transnational Care in the Case of Transnational Migration between Cuba and Germany. In: Transnational Social Review, 7(1), 1-17.

Castro Varela, M. (2013): Ist Integration nötig? Eine Streitschrift. Freiburg: Lambertus.

Düvell, F./Molodikova, I./Collyer, M. (eds.) (2014): Transit Migration in Europe. Amsterdam: Amsterdam University Press.

Fischer, W./Kohli, M. (1987): Biographieforschung. In: Voges, W. (ed.): Methoden der Biographie- und Lebenslaufforschung. Opladen: Leske \& Budrich, 25-50.

Flyvbjerg, B. (2006): Five Misunderstandings About Case-Study Research. In: Qualitative Inquiry, 12(2), 219-245.

Geertz, C. (1973): Thick Description. Toward an Interpretive Theory of Culture. In: The Interpretation of Cultures. Selected Essays. New York: Basic Books, 3-30.

Glaser, B. G./Strauss, A. L. (2008[1967]): The Discovery of Grounded Theory. Strategies for Qualitative Research. Chicago: Aldine Publishing Company.

Glick Schiller, N./Basch, L./Blanc-Szanton, C. (1992): Transnationalism. A New Analytic Framework for Understanding Migration. In: Annals of the New York Academy of Sciences, 645(1), 1-24.

Hess, S./Binder, J./Moser, J. (eds.) (2009): No integration?! Kulturwissenschaftliche Beiträge zur Integrationsdebatte in Europa. Bielefeld: transcript.

Hess, S. (2014): Für eine Migrationsforschung jenseits des Integrationsparadigmas. Tagungsdokumentation Rat für Migration: 25-34. Online: https://ratfuermigration.files.wordpress.com/2018/04/fachtagung_2013_rat_ fuer_migration.pdf $<26.05 .2020>$.

Inhetveen, K. (2013): Another Kind of Empowerment? Imported Power Structures and the International Refugee Regime in a Zambian Camp. In: Trialog, 112/113(1/2), 54-59.

Karakayali, J. (2010): Transnational Haushalten: Biographische Interviews mit "care workers" aus Osteuropa. Wiesbaden: Springer VS.

Krause, U. (2017): Escaping Conflicts and Being Safe? Post-Conflict Refugee Camps and the Continuum of Violence. In: Buckley-Zistel, S./Krause, U. (eds.): Gender, Violence, Refugees. New York/Oxford: Berghahn, 173-196.

Lewin, K. (1992): Law and Experiment in Psychology. In: Science in Context, 5(2), 385-416. 
Lutz, H. (2004): Transnationale Biographien in globalisierten Gesellschaften. In:

Ottersbach, M./Yildiz, E. (eds.): Migration in der metropolitanen Gesellschaft. Zwischen Ethnisierung und globaler Neuorientierung. Münster: Lit-Verlag, 207-216.

Minteu Kadje, D. (2017): Transnational Migration Among Migrants from Cameroon. In: Tonah, S./Setrana, M. B. (eds.): Migration and Development in Africa. Trends, Challenges, and Policy Implications. Lanham: Lexington Books, 57-68.

Nawyn, S. J. (2016): New Directions for Research on Migration in the Global South. In: International Journal of Sociology, 46(3), 163-168.

Nieswand, B. (2011): Theorising Transnational Migration. The Status Paradox of Migration. London/New York: Routledge.

Oevermann, U. (1981): Fallrekonstruktionen und Strukturgeneralisierung als Beitrag der objektiven Hermeneutik zur soziologisch-strukturtheoretischen Analyse. Unpublished manuscript. Online: http://publikationen.ub.unifrankfurt.de/ files/4955/Fallrekonstruktion-1981.pdf <15.07.2020>.

Oltmer, J. (2017): Migration aufgrund von Gewalt. Hintergründe, Bedingungen und Folgen. In: Sozialer Fortschritt, 66(11), 725-740.

Portes, A. (1997): Globalization from Below. The Rise of Transnational Communities. Online:

http://www.transcomm.ox.ac.uk/working\%20papers/portes.pdf $<26.05 .2020>$.

Pries, L. (2019): The Momentum of Transnational Social Spaces in Mexico-USMigration. In: Comparative Migration Studies, 7, Art. 34. Online: https://doi.org/10.1186/s40878-019-0135-5<31.08.2020>.

Ragin, C. C. (1992): Introduction. Cases of "What Is a Case?" In: Becker, H. S./Ragin, C. C. (eds.): What Is a Case?. Exploring the Foundations of Social Inquiry. Cambridge/New York: Cambridge University Press, 1-17.

Rosenthal, G. (1995): Erlebte und erzählte Lebensgeschichte. Gestalt und Struktur biographischer Selbstbeschreibungen. Frankfurt a. M./New York: Campus.

Rosenthal, G. (2012): A Plea for a More Interpretive, More Empirical and More Historical Sociology. In: Kalekin-Fishman, D./Denis, A. (eds.): The Shape of Sociology for the 21st Century. Tradition and Renewal. London/Thousand Oaks: Sage, 202-217. 
Rosenthal, G. (2016): Die Erforschung kollektiver und individueller Dynamik. Zu einer historisch und prozess-soziologisch orientierten interpretativen Sozialforschung. Forum Qualitative Sozialforschung 17(2). Online: http://www.qualitative-research.net/index.php/fqs/article/view/2614 $<25.06 .2020>$.

Rosenthal, G./Bahl, E./Worm, A. (2017): Illegalized Migration Courses from the Perspective of Biographical Research and Figurational Sociology. The Land Border between Spain and Morocco. In: Rosenthal, G./Bogner, A. (eds.): Biographies in the Global South. Frankfurt a. M./New York: Campus, 103159.

Schuetz, A. (1953): Common-Sense and Scientific Interpretation of Human Action. In: Philosophy and Phenomenological Research, 14(1), 1-38.

Setrana, M. B./Tonah, S. (2014): Return Migrants and the Challenge of Reintegration. The Case of Returnees to Kumasi, Ghana. In: İrìnèrindò: A Journal of African Migration, 7, 113-142.

Setrana, M. B./Tonah, S. (2016): Do Transnational Links Matter after Return? Labour Market Participation among Ghanaian Return Migrants. In: Journal of Development Studies, 52(4), 549-560.

Siouti, I. (2017): Biography as a Theoretical and Methodological Key Concept in Transnational Migration Studies. In: Godson, I./Antikainen, A./Andrews, M./Sikes, P. (eds.): The Routledge International Handbook on Narrative and Life History. Abingdon: Routledge, 179-190.

Tonah, S. (2007): Ghanaians Abroad and Their Ties Home. Cultural and Religious Dimensions of Transnational Migration. COMCAD Working Papers 25. Online: http://nbn-resolving.de/urn:nbn:de:0168-ssoar-413216 $<26.05 .2020>$.

Trzeciak, M. F./Tuider, E./Wienold, H. (2018) (eds.): Transit Mexiko. Migration, Gewalt, Menschenrechte. Münster: Westfälisches Dampfboot.

Treibel, A. (2015): Integriert Euch! Plädoyer für ein selbstbewusstes Einwanderungsland. Frankfurt a. M./New York: Campus.

Weber, M. (1949): “Objectivity” in Social Science and Social Policy. In: On the Methodology of the Social Sciences. New York: Free Press, 50-112.

Worm, A. (2019): Fluchtmigration aus Syrien. Eine biographietheoretische und figurationssoziologische Studie. Göttinger Beiträge zur soziologischen Biographieforschung, Bd. 1. Göttingen: Universitätsverlag Göttingen. Online: https://doi.org/10.17875/gup2019-1228<09.04.2020>. 